\title{
Projected Spatiotemporal Dynamics of Drought under Global Warming in Central Asia
}

\author{
Ruiwen Zhang ${ }^{1,2,3} \oplus^{\circ}$, Chengyi Zhao ${ }^{1, *}$, Xiaofei Ma ${ }^{2,3}{ }^{\circledR}$, Karthikeyan Brindha ${ }^{4}$, Qifei Han ${ }^{1}$, \\ Chaofan $\mathrm{Li}^{1}$ and Xiaoning Zhao ${ }^{2}$ \\ 1 Land Science Research Center, Nanjing University of Information Science and Technology, \\ Nanjing 210044, China \\ 2 State Key Laboratory of Desert and Oasis Ecology, Xinjiang Institute of Ecology and Geography, \\ Chinese Academy of Sciences, Urumqi 830011, China \\ 3 University of Chinese Academy of Sciences, Beijing 100049, China \\ 4 Hydrogeology Research Group, Institute of Geological Sciences, Free University of Berlin, \\ 10115 Berlin, Germany \\ * Correspondence: zhaocy@nuist.edu.cn; Tel./Fax: +86-25-5823-5199
}

Received: 31 May 2019; Accepted: 13 August 2019; Published: 15 August 2019

\begin{abstract}
Drought, one of the most common natural disasters that have the greatest impact on human social life, has been extremely challenging to accurately assess and predict. With global warming, it has become more important to make accurate drought predictions and assessments. In this study, based on climate model data provided by the Inter-Sectoral Impact Model Intercomparison Project (ISIMIP), we used the Palmer Drought Severity Index (PDSI) to analyze and project drought characteristics and their trends under two global warming scenarios $-1.5^{\circ} \mathrm{C}$ and $2.0^{\circ} \mathrm{C}-$ in Central Asia. The results showed a marked decline in the PDSI in Central Asia under the influence of global warming, indicating that the drought situation in Central Asia would further worsen under both warming scenarios. Under the $1.5{ }^{\circ} \mathrm{C}$ warming scenario, the PDSI in Central Asia decreased first and then increased, and the change time was around 2080, while the PDSI values showed a continuous decline after 2025 in the $2.0^{\circ} \mathrm{C}$ warming scenario. Under the two warming scenarios, the spatial characteristics of dry and wet areas in Central Asia are projected to change significantly in the future. In the $1.5{ }^{\circ} \mathrm{C}$ warming scenario, the frequency of drought and the proportion of arid areas in Central Asia were significantly higher than those under the $2.0^{\circ} \mathrm{C}$ warming scenario. Using the Thornthwaite (TH) formula to calculate the PDSI produced an overestimation of drought, and the Penman-Monteith (PM) formula is therefore recommended to calculate the index.
\end{abstract}

Keywords: PDSI; Central Asia; climate model; Thornthwaite method; Penman-Monteith method

\section{Introduction}

Drought is a natural phenomenon that deteriorates the affected region's ecological environment due to long-term deficits in precipitation and subsequent shortages in water supply [1,2]. Drought not only affects the growth of crops and influences global food prices, but also contributes to political unrest [3]. In accord with a broad range of affected systems, drought is divided into three categories: agricultural drought, climate drought, and hydrological drought [4-6]. Drought poses a serious threat to social and economic development: it caused the loss of over $\$ 200$ billion between 1980 and 2014 [7] and has become the most serious natural disaster threatening human life and property [4]. According to the "Fifth Assessment Report of the Intergovernmental Panel on Climate Change (IPCC)" [8], global warming will have an extremely negative impact on human and natural ecosystems. As the temperature increases under global warming, the potential increase in evapotranspiration and temperature will 
lead to a further increase in the frequency and scale of drought [9]. Therefore, it is necessary to predict and assess the risk of drought that may occur in the event of future global warming in order to adopt measures to reduce the damage caused to people's lives and livelihoods.

Research into the occurrence, severity, and extent of the impact of drought has been an arduous and time-consuming task due to the complexity of the drivers [10]. To quantitatively evaluate the effects of drought, researchers typically use factors such as precipitation, soil moisture, and evapotranspiration, or a combination of these [11-16]. Many indicators taking into account different hydrological processes have been proposed to quantify the magnitude of drought $[17,18]$. Common drought indicators include the Palmer Drought Severity Index (PDSI) [19], the Surface Wetness Index (SWI) [20], the Standardized Precipitation Index (SPI) [21], and the Standardized Precipitation-Evapotranspiration Index (SPEI) [22]. Among them, the PDSI is widely used in drought monitoring and detection and is based on the influence of the magnitude of the water deficit, drought duration, water balance, a comprehensive consideration of antecedent weather conditions, soil water content, and evapotranspiration [23]. The empirical parameters used in the initial calculation of the PDSI were determined from observational data from the midwestern United States, which leads to certain problems in the applicability of the PDSI to other regions [24]. Based on monthly precipitation and temperature data, Dai et al. [25] used the PDSI to calculate the global drought index distribution during 1900-1995, which indicated that an increase in the percentage of both dry and wet areas is closely related to global warming and a shift in the El Niño Southern Oscillation (ENSO) since the 1970s. In the 21st century, a self-calibrated PDSI (scPDSI) method was proposed based on the original PDSI method and the use of historical data for each site to correct the empirical coefficient in the original PDSI equation [26]. After the scPDSI method was proposed, many researchers conducted comparative analyses of the results obtained using the PDSI and scPDSI and found that in most areas, the correlation between the two was good. Moreover, under certain extreme weather conditions, there were limited differences between the two drought indices [27-31]. Despite continuous improvements to the PDSI, the original PDSI is still suitable for the assessment of drought. In the past, the Thornthwaite (TH) empirical formula was used to determine the potential evapotranspiration (ETp) in the calculation of the PDSI [32,33]. However, the Penman-Monteith (PM) formula has a clearer physical meaning than the TH formula. Nevertheless, despite the large differences between the ETp values calculated using the two formulas (PM and TH), the final calculated PDSI results are similar [34]. Dai [28] used different methods to calculate ETp values using global temperature and precipitation data from 1900 to 2008 and found that the differences between the results obtained using different methods were minor.

Since the beginning of the 21st century, increasing numbers of studies have reported global warming $[8,35,36]$. By 2050, global temperatures are projected to rise by $0.7-2.4{ }^{\circ} \mathrm{C}$ compared to the period 1986-2005 [37,38]. To reduce the risks and impacts of frequent natural disasters caused by global warming, the United Nations Framework Convention on Climate Change (UNFCCC) has stressed the need to maintain the increase in the global average surface temperature to well below $2.0^{\circ} \mathrm{C}$ above preindustrial levels and to pursue efforts to limit the temperature increase to $1.5^{\circ} \mathrm{C}$ above preindustrial levels [7,35]. Many studies have shown that under an extreme global climate, and particularly under warming conditions, the frequency of drought will increase [39-43]. The Coupled Model Intercomparison Project Phase 5 (CMIP5), organized by the World Climate Research Programme (WCRP), provides multimodel simulations for predicting climate changes [44,45]. Using two climate models and four drought indices, Burke et al. [46] produced global drought simulations. They identified large uncertainties in the changes in drought severity in arid regions and stressed the consequent need for the use of an appropriate drought index. Significant differences in predicted PDSI values were reported between eastern and western China in the CMIP5 [47]. The predicted PDSI values under the representative concentration pathway (RCP) 4.5 scenario indicated that the number of droughts in western China would increase and that the size of the wet areas would decrease $[48,49]$. Central Asia is the largest nonzonal arid region in the world and is currently experiencing the most serious ecological degradation in Asia. This includes frequent and severe droughts [50,51]. Drought 
has become the dominant factor constraining the economic and social development of Central Asia. However, relatively few studies have assessed droughts in Central Asia, and these studies have relied mainly on a small number of ground observation sites and have provided evaluations for small spatial regions with limited time scales.

In this study, we used calibrated climate model data from the Inter-Sectoral Impact Model Intercomparison Project (ISIMIP) to calculate the PDSI in Central Asia to analyze the spatiotemporal variations of drought in that region under two different warming scenarios- $1.5^{\circ} \mathrm{C}$ and $2.0^{\circ} \mathrm{C}$ - and to explore and analyze the meteorological factors affecting the PDSI. Our objectives were (1) to study the proportion of arid areas in Central Asia from 1861 to 2099 based on the PDSI, as well as the drought trend and frequency; (2) to compare the variation law and characteristics of drought under the two warming scenarios in Central Asia; and (3) to compare two methods of calculating the PDSI, namely PDSI_PM, which uses the PM formula to calculate the evapotranspiration, and PDSI_TH, which uses the TH formula.

\section{Materials and Methods}

\subsection{Study Area}

The Central Asian region (covering an area of $563.8 \times 10^{4} \mathrm{~km}^{2}$ ) includes Turkmenistan, Kyrgyzstan, Uzbekistan, Tajikistan, Kazakhstan, and the Xinjiang region of China (Figure 1). It is located between 34.34 and $55.43^{\circ} \mathrm{N}$ and between 46.49 and $96.37^{\circ} \mathrm{E}$. The region experiences a typical continental climate of an inland arid area, with cold winters, hot summers, and low annual precipitation ranging from 125 to $289 \mathrm{~mm}[52,53]$. Precipitation in the region is generally lower in the eastern and western regions. Evaporation greatly exceeds precipitation, and the average annual temperatures are highly variable.

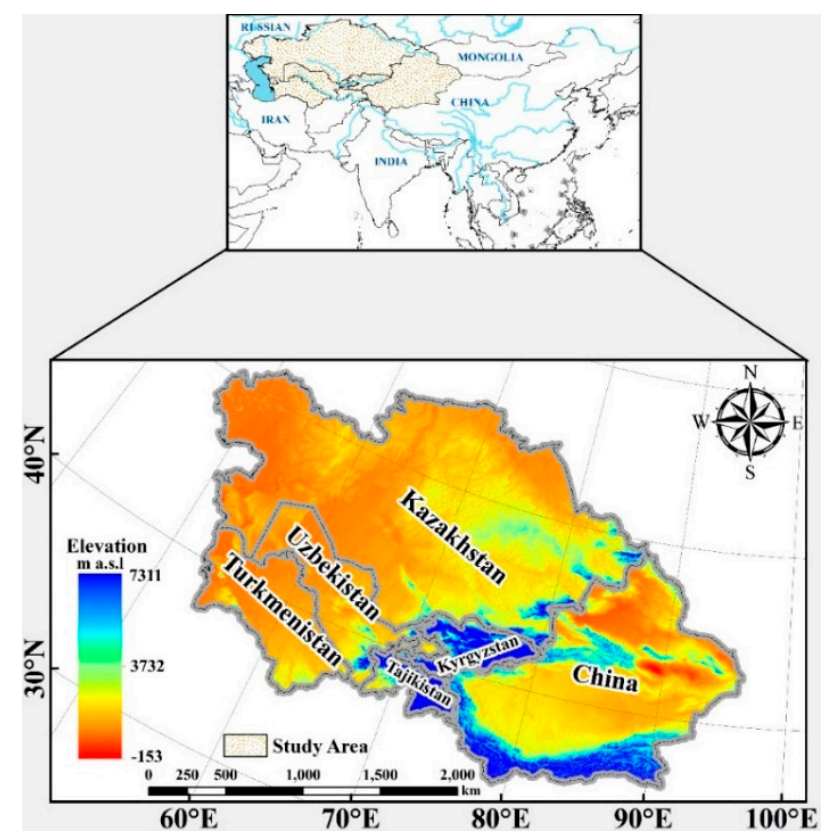

Figure 1. Location of Central Asia.

\subsection{Global Warming Scenarios of $1.5^{\circ} \mathrm{C}$ and $2.0^{\circ} \mathrm{C}$}

The IPCC Fifth Assessment Report showed that the mean global surface temperature increased by $0.61{ }^{\circ} \mathrm{C}$ from 1986 to 2005 compared to preindustrial levels [54]. Global warming of $1.5^{\circ} \mathrm{C}$ and $2.0^{\circ} \mathrm{C}$ can be defined through different methods [55]. Besides, due to differences in the data used, the evaluation results are also different $\left(1.5^{\circ} \mathrm{C}\right.$ and $2.0^{\circ} \mathrm{C}$ warming thresholds will be reached point-in-time). The $1.5^{\circ} \mathrm{C}$ and $2.0^{\circ} \mathrm{C}$ warming thresholds will be reached in 2020-2039 (RCP2.6, 
corresponding to increases in radiative forcing in the year 2100 being $2.6 \mathrm{~W} / \mathrm{m}^{2}$ relative to preindustrial values) and 2040-2059 (RCP4.5) according to ISIMIP data, respectively [56].

\subsection{Climate Modeling Data}

This article uses ISIMIP- $2 \mathrm{~b}$ climate model data. ISIMIP-2b provides multiple bias-corrected climate models from the CMIP5. We selected four climate models (GFDL-ESM2M, MIROC5, IPSL-CM5A-LR, and HadGEM2-ES) under the RCP2.6 and RCP4.5 scenarios. Specific information on the four climate models is shown in Table 1. To facilitate the comparison, the four model datasets are regridded to a horizontal grid resolution of $0.5^{\circ} \times 05^{\circ}$ using a bilinear interpolation algorithm for the Northern China region. The climate model data used in this study ranged from 1861 to 2099, with a total of 239 years of climate model data. The climate model data included precipitation, minimum temperature, maximum temperature, wind speed, shortwave radiation, specific humidity, altitude, elevation, albedo, latitude, and longitude. Information on the soil effective water holding capacity (AWC) was sourced from the Regridded Harmonized World Soil Database (https://daac.ornl.gov).

Table 1. List of the four Inter-Sectoral Impact Model Intercomparison Project (ISIMIP) climate models used in the analysis.

\begin{tabular}{cccc}
\hline Model & Institution & Country & $\begin{array}{c}\text { Original Resolution } \\
\text { (Lat } \times \text { Lon) }\end{array}$ \\
\hline GFDL-ESM2 M & Geophysical Fluid Dynamics Laboratory & USA & $2.5^{\circ} \times 2.0^{\circ}$ \\
HadGEM2-ES & Met Office Hadley Center & UK & $1.875^{\circ} \times 1.258^{\circ}$ \\
IPSL-CM5A-LR & Institute Pierre Simon Laplace & France & $3.75^{\circ} \times 1.98^{\circ}$ \\
MIROC5 & Model for Interdisciplinary Research on Climate & Japan & $1.4^{\circ} \times 1.4^{\circ}$ \\
\hline
\end{tabular}

\subsection{Drought Index Calculation}

Palmer defined drought as the period of time in months or years during which the actual water supply is lower than the expected water supply [19]. The calculation of the PDSI is based on a simple two-layer soil model that is based on the following assumptions: (1) moisture cannot be removed from the lower soil layer until all available moisture has been removed from the surface soil layer; (2) runoff occurs only when both the surface soil layer and lower soil layer are saturated; (3) evapotranspiration loss from the surface soil layer takes place at a potential rate; and (4) evapotranspiration loss from the lower soil layer depends on the initial moisture content of this layer and the combined AWC values in both soil layers [24]. The amount of water exchanged between the two soil layers is calculated by a soil-water balance equation, and the precipitation $(\hat{P})$ is calculated as follows:

$$
\hat{P}=\alpha_{i} P E+\beta_{i} P R+\gamma_{i} P R O-\delta_{i} P L
$$

where $\hat{P}$ represents the amount of precipitation needed to maintain a normal soil moisture level for a month; $P E, P R, P R O$, and $P L$ represent potential evapotranspiration, potential soil water recharge, potential runoff, and loss, respectively; and $\alpha, \beta, \gamma$, and $\delta$ represent their respective coefficients. These coefficients are calculated as follows:

$$
\alpha_{i}=\frac{\overline{\overline{E T_{i}}}}{\overline{\overline{P E_{i}}}} \quad \beta_{i}=\frac{\overline{R_{i}}}{\overline{\overline{P R_{i}}}} \quad \gamma_{i}=\frac{\overline{R O_{i}}}{P R O_{i}} \quad \delta_{i}=\frac{\overline{L_{i}}}{\overline{P L_{i}}} .
$$

The bar over each parameter in Equation (2) represents the average value over multiple months; and $E T, R, R O$, and $L$ represent the evapotranspiration, soil water recharge, runoff, and loss, respectively [57].

The difference between the actual precipitation $(P)$ in a given month and the computed precipitation $(\hat{P})$ under the existing conditions is called the moisture departure $(d)$. This parameter is calculated as follows:

$$
d=P-\bar{P}=P-\left(\alpha_{i} P E+\beta_{i} P R+\gamma_{i} P R O-\delta_{i} P L\right) .
$$


The moisture departure can have different meanings for the surface water balance at different locations and at different times. To correct for this, the moisture departure was weighted by the climate characteristic coefficient $(K)$ of the corresponding month, where $K$ for month $i$ was defined by Palmer (using data from the central United States) as follows:

$$
\begin{gathered}
K_{i}=\frac{17.67}{\sum_{j=1}^{12} \overline{D_{j}} K_{J}^{\prime}} K_{i}^{\prime} \\
K_{i}^{\prime}=1.5 \log _{10}\left[\frac{\overline{\frac{P E_{i}}{}+\overline{R_{i}}+\overline{R_{i}}}+2.8}{\overline{\bar{P}_{i}}+\overline{L_{i}}}\right]+0.5,
\end{gathered}
$$

where $K_{i}^{\prime}$ is Palmer's general approximation for the climate characteristic of a location, $\overline{D_{i}}$ is the average moisture departure for the corresponding month, and 17.67 is an empirical constant.

Multiplying $d$ and $K$ gives what is called the moisture anomaly index $(Z)$, or Palmer's $Z$, as shown in Equation (6):

$$
Z=d k
$$

The $Z$ index is used to show how wet or dry it was during a given month without regard to recent precipitation trends [26]. The $Z$ index was used to compute the PDSI value for a given month using the general formula

$$
X_{i}=0.897 X_{i-1}+\left(\frac{1}{3}\right) Z_{i}
$$

where $X_{i}$ is the PDSI value of the current month and $X_{(i-1)}$ is the PDSI value of the previous month. The quantities 0.897 and $1 / 3$ are called the duration factors. Table 2 provides the PDSI dryness and wetness grading standards [26].

Table 2. The Palmer Drought Severity Index (PDSI) dryness/wetness grade.

\begin{tabular}{cccc}
\hline PDSI & Wet and Dry Grade & PDSI & Wet and Dry Grade \\
\hline$\geq 4$ & Extremely wet & $\geq-2 \sim-1$ & Mild drought \\
$\geq 3 \sim 4$ & Very wet & $\geq-3 \sim-2$ & Moderate drought \\
$\geq 2 \sim 3$ & Moderately wet & $\geq-4 \sim-3$ & Severe drought \\
$\geq 1 \sim 2$ & Slightly wet & $<-4$ & Extreme drought \\
\hline
\end{tabular}

Jacobi et al. [58] developed a program to calculate the PDSI using MATLAB software (MathWorks, Natick, MA, USA). In the program, the Thornthwaite formula is used to calculate ETp. Additionally, Ficklin et al. [59] developed an improved version of the original PDSI program that added a variety of potential evaporation formulas, including the Penman-Monteith formula (recommended by FAO), and further optimized the PDSI calculation program [34]. In this study, we used the improved version of Ficklin et al. [59] to calculate the PDSI in Central Asia. First, climate model data for Central Asia were extracted from ISIMIP- $2 \mathrm{~b}$, and then the various data were normalized according to the PDSI program. Finally, monthly PDSI values for all sites in Central Asia were obtained by running the model.

\subsection{Statistical Analysis}

The Mann-Kendall (M-K) trend analysis method [60] was used to analyze the trend and change in PDSI values under the two warming scenarios $\left(1.5^{\circ} \mathrm{C}\right.$ and $\left.2.0^{\circ} \mathrm{C}\right)$ in Central Asia. The empirical orthogonal function (EOF) was used to explore the future variations in the spatial distribution of the PDSI values in Central Asia under the warming scenarios. EOF analysis decomposes the spatiotemporal variable field to the spatial function of a single variable and the temporal function of a single variable and can be utilized to objectively explain the structure of the variability within a dataset to analyze relationships between a set of variables [61]. In the EOF analysis, the PDSI data throughout 
Central Asia were first preprocessed by anomaly analysis to obtain the corresponding matrix. Then, the cross-product of the matrix and its transpose matrix was calculated to obtain the square matrix, and the eigenvalues and eigenvectors of the square matrix were calculated. The eigenvector obtained was the EOF mode corresponding to the eigenvalues. Finally, the EOF was projected onto the original matrix to obtain the temporal coefficients corresponding to the spatial eigenvectors. MATLAB was used for all of the calculation processes implemented to analyze the data [62]. The framework of this study was as follows (in Figure 2).

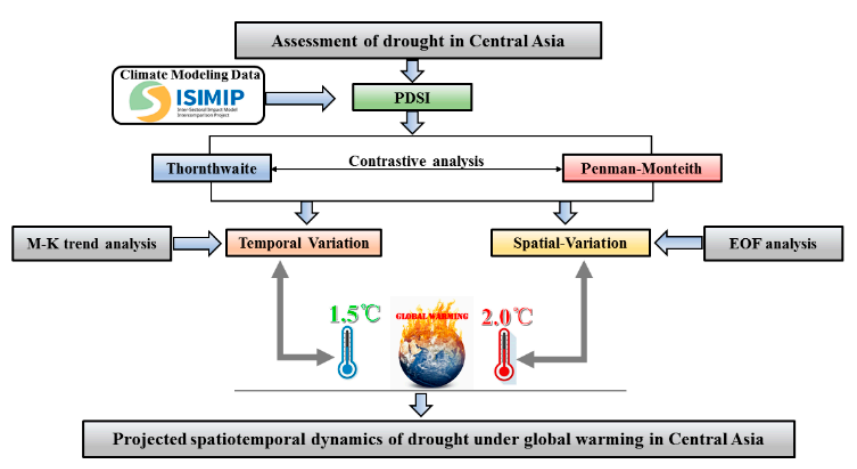

Figure 2. Framework of this study.

\section{Results}

\subsection{Temporal Variation in the Palmer Drought Severity Index (PDSI)}

The temporal variation in the PDSI in Central Asia under the warming scenarios $\left(1.5^{\circ} \mathrm{C}\right.$ and $2.0^{\circ} \mathrm{C}$ ) was analyzed. The annual PDSI in Central Asia, shown in Figure 3, is the result of a weighted average based on the different climate models. From 1861 to 2099, the PDSI showed a downward trend under both scenarios, indicating that future drought would intensify, particularly after 2000 (Figure 3). Under different warming scenarios, the PDSI in Central Asia showed an obvious interannual variation. Central Asia was predicted to be in a drought state between 2000 and 2099 under both warming scenarios, as the shift from wet to dry conditions was more pronounced; however, under both future scenarios, the results were in the mild drought category, as shown in Table 2. Under global warming $\left(1.5^{\circ} \mathrm{C}\right.$ and $\left.2.0^{\circ} \mathrm{C}\right)$, the calculation of the PDSI using the PM and TH formulas obtained different results between 1861 and 2005. After 2005, due to the further rise in global temperature, the PDSI values obtained by the two methods were similar, reflecting a dry state. This was consistent with the results of Dai [28].
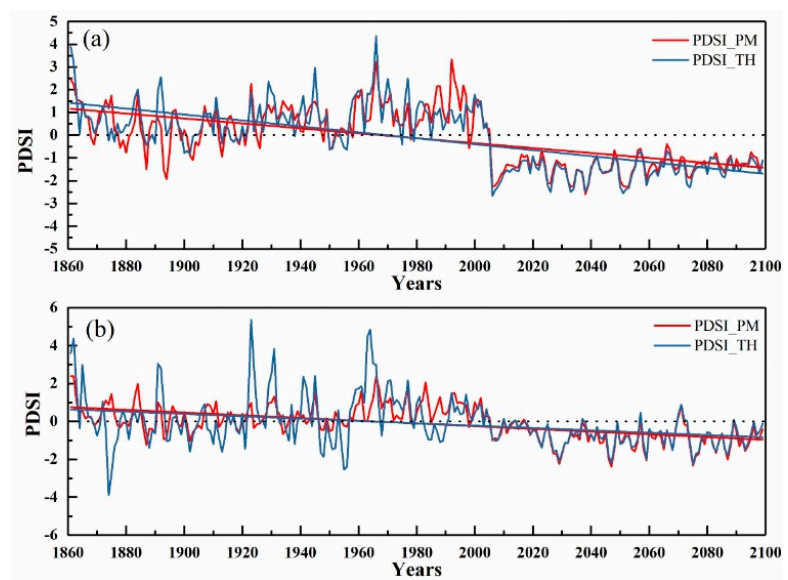

Figure 3. The annual Palmer Drought Severity Index (PDSI) in Central Asia under global warming scenarios of $1.5^{\circ} \mathrm{C}(\mathbf{a})$ and $2.0^{\circ} \mathrm{C}(\mathbf{b})$. PDSI_PM: PDSI calculated by the Penman-Monteith (PM) formula; PDSI_TH: PDSI calculated by the Thornthwaite (TH) formula. 
Under the global warming scenarios of $1.5^{\circ} \mathrm{C}$ and $2.0^{\circ} \mathrm{C}$, the PDSI showed a significant downward trend compared to the historical reference period (1986-2005) (Figure 4). In the $1.5^{\circ} \mathrm{C}$ warming scenario, the mean PDSI values during the historical period (1986-2005) were 1.37 and 1.16 for the PM and TH calculations, respectively, and those for the $2.0^{\circ} \mathrm{C}$ warming scenario were 0.73 and 0.48 for the PM and TH calculations, respectively. For temperature rises of $1.5{ }^{\circ} \mathrm{C}$ and $2.0^{\circ} \mathrm{C}$, the PDSI was below zero, indicating a significant drought. Similar trends in the PDSI were obtained by the PM (Figure 4a) and TH (Figure $4 \mathrm{~b}$ ) calculations. The aridification of Central Asia was notable under both scenarios post-2005, although there were differences between the PDSI values for each scenario. The mean PDSI obtained for the $1.5^{\circ} \mathrm{C}$ warming scenario $(-1.36)$ was lower than that obtained for the $2.0^{\circ} \mathrm{C}$ warming scenario (-0.98), indicating a more serious drought under the former scenario. In the $1.5^{\circ} \mathrm{C}$ warming scenario, the rates of PDSI change obtained using the PM formula and the TH formula were $-0.197 /$ per decade and $-0.159 /$ per decade, respectively. In the $2.0^{\circ} \mathrm{C}$ warming scenario, the rates of PDSI change obtained using the PM formula and the TH formula were $-0.185 /$ per decade and $-0.094 /$ per decade, respectively. Overall, both methods showed decreasing PDSI trends.
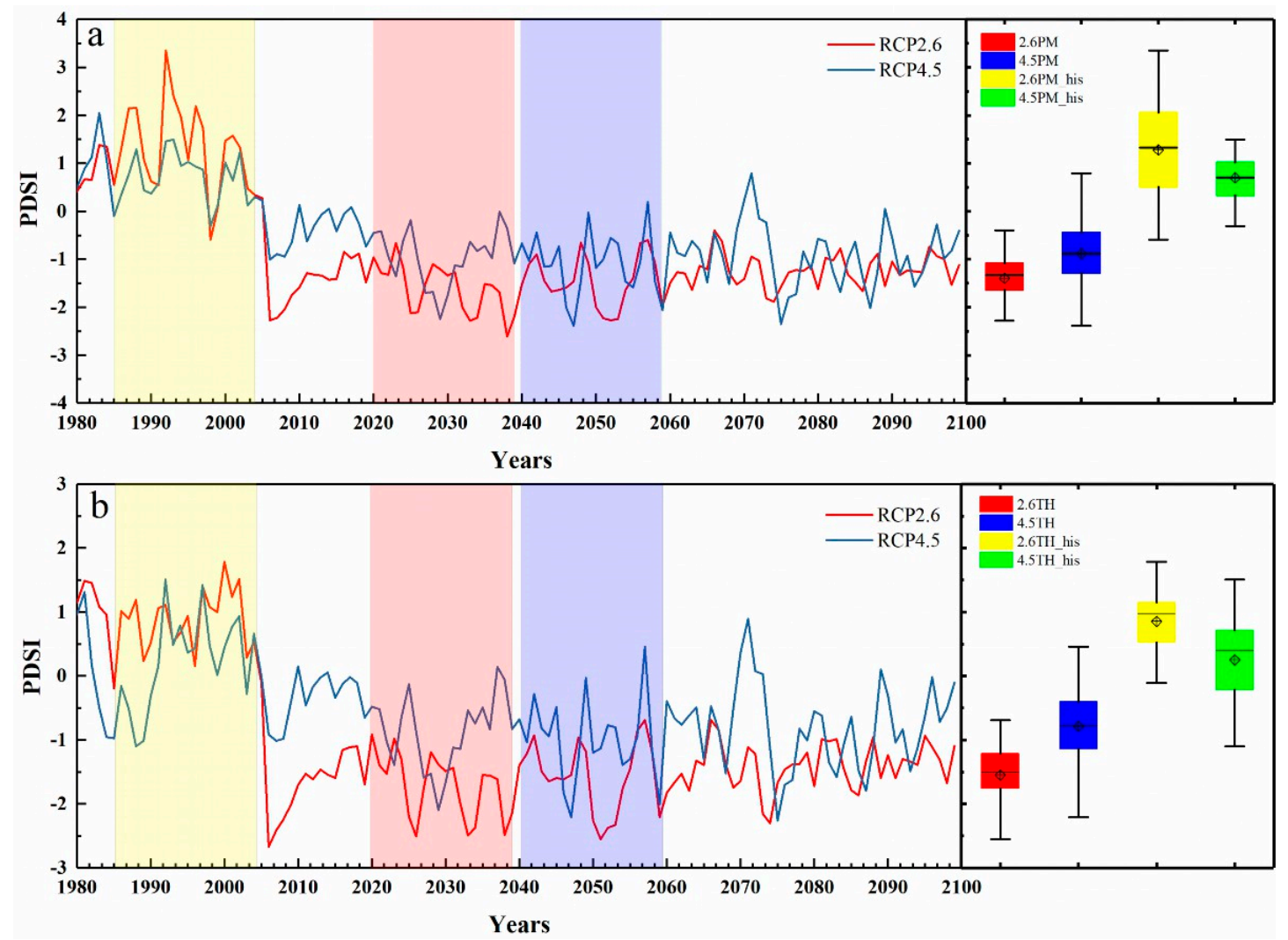

Figure 4. Interannual variation in the PDSI in Central Asia under warming scenarios of $1.5^{\circ} \mathrm{C}$ and $2.0^{\circ} \mathrm{C}$ as a 10-year moving average obtained using the PM formula (a) and the TH formula (b). The yellow shaded area is the historical reference period (1986-2005), the red shaded area is the $1.5^{\circ} \mathrm{C}$ warming scenario (2020-2039), and the blue shaded area is the $2.0^{\circ} \mathrm{C}$ scenario (2040-2059).

The M-K trend test was used to analyze the PDSI values under different conditions in order to explore the variation trends and changes of the PDSI in Central Asia. The M-K trend analysis indicated that the PDSI values in the different periods were significantly different. In historical period 1861-2005, the M-K trend analysis showed that PDSI values in Central Asia decreased first and then increased. From 1861 to 1940, PDSI values in Central Asia showed a decreasing trend. The PM formula calculation indicated that the PDSI change point occurred around 1960, while the TH formula calculation showed that the change point occurred around 1940 (Figure 5a,b). After the change point, PDSI values began to increase in Central Asia, and the trend in the PDSI increased further after $1990(\alpha=0.05)$. 

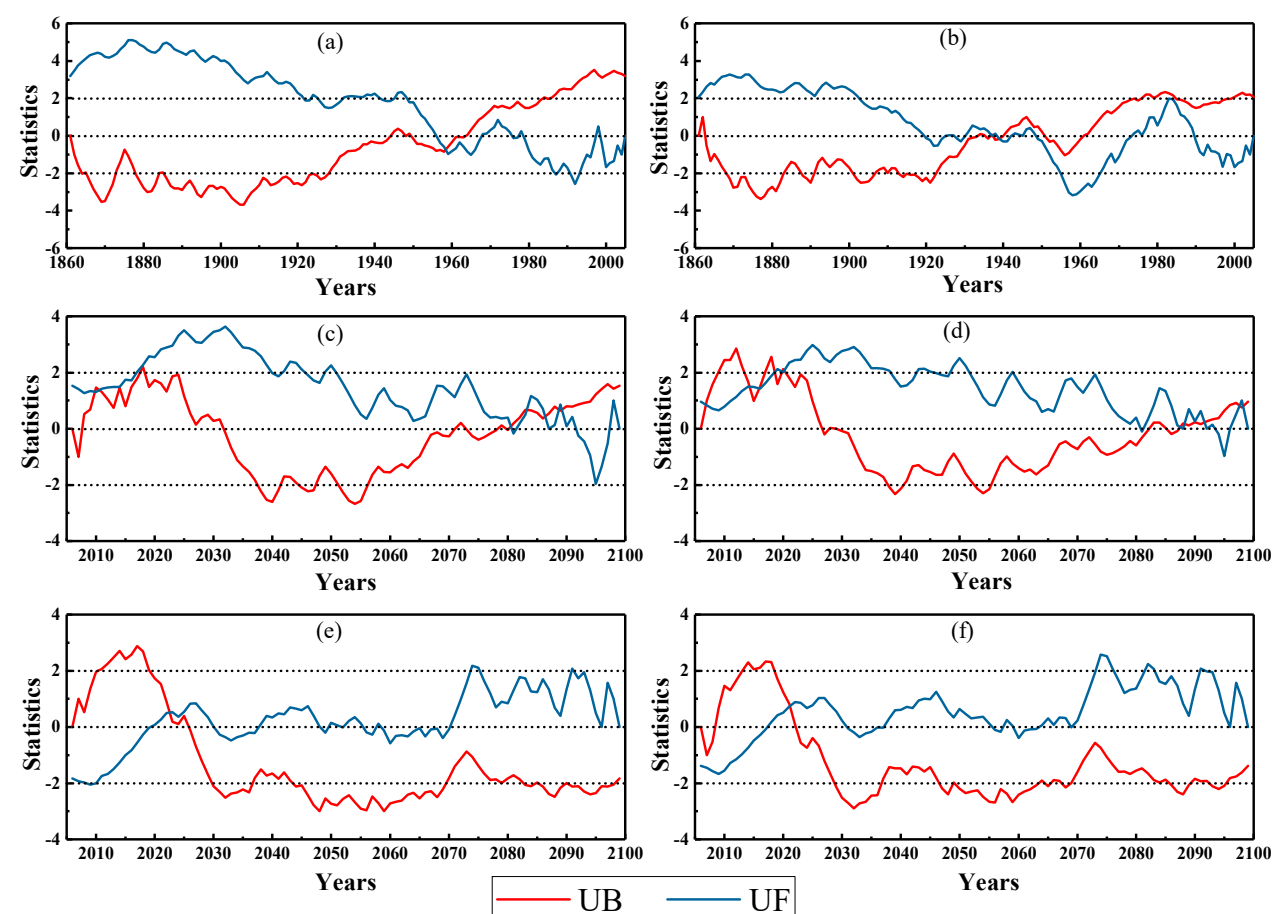

Figure 5. Mann-Kendall (M-K) trend analysis of changes in the PDSI in Central Asia. (a) PDSI_PM during the historical period. (b) PDSI_TH during the historical period. (c) PDSI_PM under the $1.5^{\circ} \mathrm{C}$ warming scenario. (d) PDSI_TH under the $1.5^{\circ} \mathrm{C}$ warming scenario. (e) PDSI_PM under the $2.0^{\circ} \mathrm{C}$ warming scenario. (f) PDSI_TH under the $2.0^{\circ} \mathrm{C}$ warming scenario.

The results of the calculation with the PM formula showed that in different warming scenarios $\left(1.5^{\circ} \mathrm{C}\right.$ and $\left.2.0^{\circ} \mathrm{C}\right)$, the overall PDSI trend first increased and then decreased. Under the $1.5^{\circ} \mathrm{C}$ warming scenario, the PDSI showed an increasing change from 2010 to 2030 and then decreased after 2030, with a significant downward trend around 2055. The change point in the PDSI appeared around 2080, and the change in the PDSI increased after the change point. Under the $2.0^{\circ} \mathrm{C}$ warming scenario, PDSI values presented an increasing change between 2010 and 2025. The change point occurred around 2025, and the PDSI showed a downward trend from the change point to 2100, with a significant downward trend from 2045 to $2070(\alpha=0.05)$. The PDSI trend calculated with the TH formula was similar to that calculated by the PM formula under different warming scenarios. Under the $1.5^{\circ} \mathrm{C}$ warming scenario, the $\mathrm{M}-\mathrm{K}$ trend analysis of the PDSI obtained by the two calculation formulas both showed a trend of increasing first and then decreasing, but there were some differences in the change point. The $\mathrm{M}-\mathrm{K}$ trend analysis of the PDSI obtained by the two calculation formulas had a similar trend in the $2.0^{\circ} \mathrm{C}$ warming scenario, and the change point was also very close.

\subsection{Spatial Variation in the PDSI}

To calculate the drought frequency in the entire study period, the PDSI values for all years in the study period were counted, and when the PDSI was less than -1 , the year was recorded as a drought year. This drought frequency was used to assess the frequency of drought in Central Asia. In the base period, the drought frequency was mainly between $0 \%$ and $40 \%$ in most parts of Central Asia, although it was higher than $60 \%$ in certain areas. Similar spatial distributions of the PDSI were obtained using the PM and TH formulas (Figure 6(a1,a2)). The spatial distribution of drought frequency in Central Asia was similar under the two warming scenarios. The frequency of drought in most parts of Turkmenistan was between $20 \%$ and $40 \%$, with certain regions in southern Turkmenistan exhibiting values greater than $40 \%$ and certain areas even exceeding $60 \%$, which represented a high frequency in Central Asia. In parts of southwest Kazakhstan and northern Xinjiang, the drought frequencies also exceeded $40 \%$. 
Under the $1.5^{\circ} \mathrm{C}$ warming scenario (Figure $6(\mathrm{~b} 1, \mathrm{~b} 3)$ ), the frequency of drought increased significantly, exceeding $40 \%$ in most areas, especially in the northern part of Turkmenistan, the central part of Uzbekistan, and most of the central and southern parts of Xinjiang, where the drought frequency was higher than $80 \%$. In regions with historically low drought frequencies, such as the northern part of Kazakhstan and parts of northern Xinjiang, the drought frequency was between $20 \%$ and $40 \%$. The PDSI results obtained using the PM and TH formulas were similar across the entire study area, although differences were observed in certain areas. In the $2.0^{\circ} \mathrm{C}$ warming scenario (Figure $6(\mathrm{~b} 2, \mathrm{~b} 4)$ ), the drought frequency was lower than that under the $1.5^{\circ} \mathrm{C}$ warming scenario, and it was mainly between $40 \%$ and $80 \%$ in most parts of the study area, although it was higher than $80 \%$ in central Xinjiang and parts of Turkmenistan. Under the $1.5{ }^{\circ} \mathrm{C}$ and $2.0^{\circ} \mathrm{C}$ warming scenarios, the drought frequency in Central Asia was $67.6 \%$ and $54.8 \%$, respectively. Compared to the $2.0^{\circ} \mathrm{C}$ warming scenario, the $1.5{ }^{\circ} \mathrm{C}$ warming scenario was more likely to lead to drought in Central Asia.

By comparing the warming and baseline periods, it was clear that the drought frequency throughout the region showed a significant increasing trend higher than $40 \%$ for most regions. Under the $1.5^{\circ} \mathrm{C}$ warming scenario (Figure $6(\mathrm{c} 1, \mathrm{c} 3)$ ), the frequency of drought increased significantly in most of Central Asia and reached up to $80 \%$ in most parts of south-central Xinjiang and parts of Kazakhstan. Compared to the baseline period, parts of Turkmenistan and northern Xinjiang showed a declining drought frequency, usually below $40 \%$. Under the $2.0^{\circ} \mathrm{C}$ warming scenario (Figure $6(\mathrm{c} 2, \mathrm{c} 4)$ ), the increase in the frequency of drought was evident in most regions, including most parts of Uzbekistan, southern Kazakhstan, and southern Xinjiang. While the drought frequency was generally greater than $40 \%$, decreasing drought frequency was evident for a small part of Turkmenistan and northern Xinjiang, i.e., a drought frequency more than $20 \%$ lower than that of the base period. In this case, the PDSI results using the PM and TH formulas were similar.
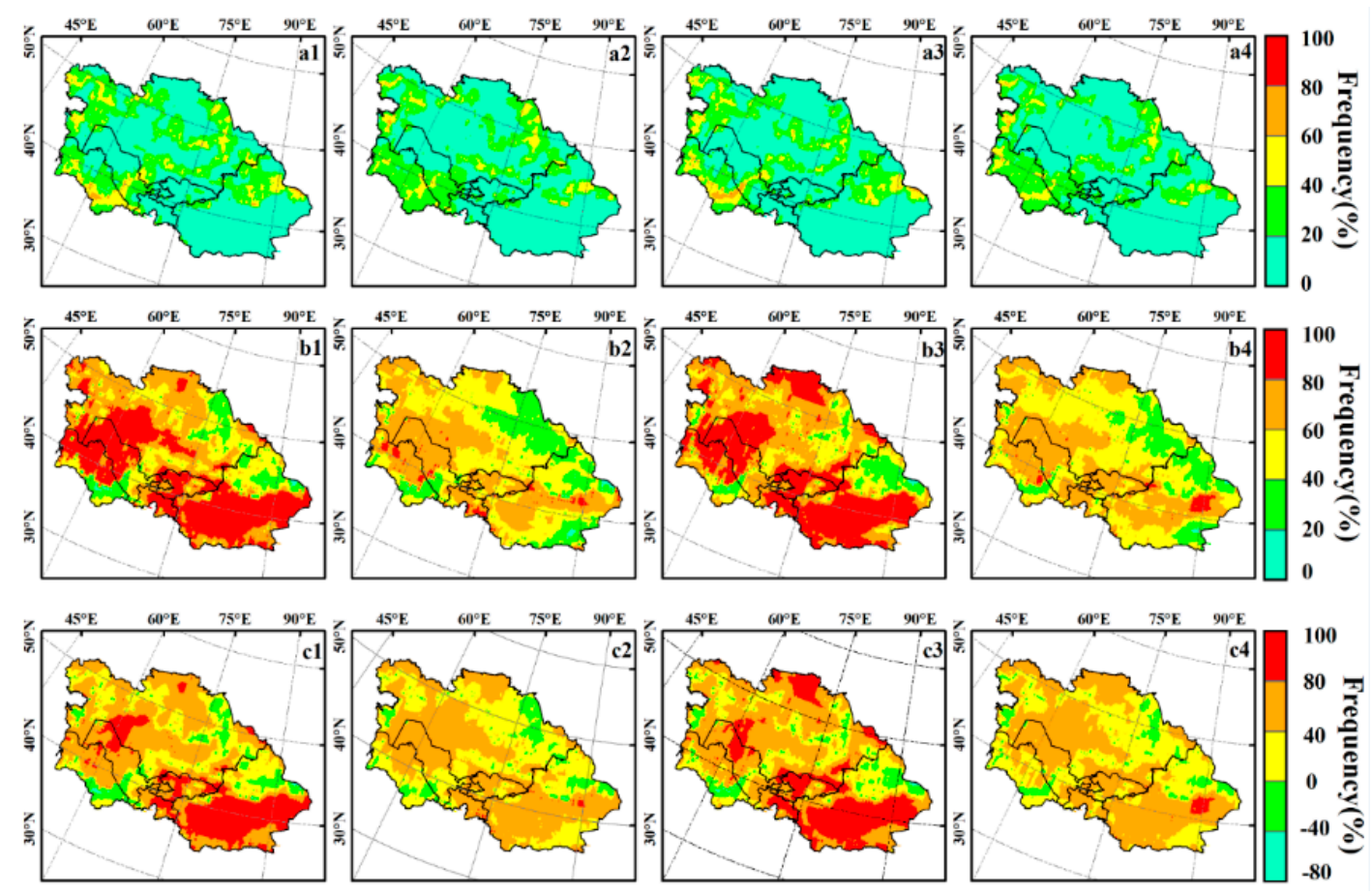

Figure 6. Spatial distribution of the drought frequency in Central Asia under the $1.5^{\circ} \mathrm{C}$ warming scenario and $2.0^{\circ} \mathrm{C}$ warming scenario, ' $\mathrm{a}$ ' Base period, 1986-2005, ' $\mathrm{b}$ ' the periods of temperature rise for the $1.5^{\circ} \mathrm{C}$ and $2.0^{\circ} \mathrm{C}$ scenarios, ' $c$ ' the change in the drought frequency relative to the base period (1986-2005) during the warming period. The different numbers in the top right-hand corners of the maps represent different simulation results: 1 denotes the PDSI_PM under the $1.5^{\circ} \mathrm{C}$ warming scenario, 2 denotes the PDSI_PM under the $2.0^{\circ} \mathrm{C}$ warming scenario, 3 denotes the PDSI_TH under the $1.5^{\circ} \mathrm{C}$ warming scenario, and 4 denotes the PDSI_TH under the $2.0^{\circ} \mathrm{C}$ warming scenario. 
The first modal variance contribution rates of the PDSI in the EOF analysis under the four conditions-the $1.5^{\circ} \mathrm{C}$ warming scenario using the PM formula, the $1.5^{\circ} \mathrm{C}$ warming scenario using the $\mathrm{TH}$ formula, the $2.0^{\circ} \mathrm{C}$ warming scenario using the PM formula, and the $2.0^{\circ} \mathrm{C}$ warming scenario using the TH formula-in Central Asia were 27.4\%, 38.7\%, 22.6\%, and 68.7\%, respectively (Figure 7). The first mode of the EOF could reflect the spatial distribution characteristics of the most dominant spatial distribution of drought in Central Asia [63]. Thus, the first mode of drought was analyzed in our study. In the PM formula, the spatial distribution characteristics of the PDSI results under the warming scenarios $\left(1.5^{\circ} \mathrm{C}\right.$ and $\left.2.0^{\circ} \mathrm{C}\right)$ in Central Asia were different. There were positive and negative PDSI spatial coefficients throughout Central Asia, indicating that there were both wet and dry areas in the study area under the different warming scenarios (Figure $7 \mathrm{a}, \mathrm{b}$ ). Under the $1.5^{\circ} \mathrm{C}$ warming scenario (Figure 7a), the spatial coefficient for most of Central Asia was greater than zero, while the spatial coefficient of southern Xinjiang, Northern Kazakhstan, and parts of Turkmenistan was less than zero. The corresponding temporal coefficient was significantly different from year to year $(\alpha<0.05)$, suggesting frequent changes in dry and wet characteristics in Central Asia in the future. Between 2005 and 2100, the temporal coefficient of most years was positive, indicating that most parts of Central Asia were in a humid state, while drought occurred in southern Xinjiang, parts of northern Kazakhstan, and parts of Turkmenistan. The negative temporal coefficient indicated that the distributions of dry and wet areas in Central Asia showed opposite changes. Under the $2.0^{\circ} \mathrm{C}$ scenario (Figure $7 \mathrm{~b}$ ), compared to the $1.5^{\circ} \mathrm{C}$ scenario, the regions with a negative spatial coefficient in Central Asia were significantly larger than the regions with a positive spatial coefficient, and the results of the PDSI showed that the spatial coefficient was positive in the western and eastern parts of Kazakhstan and the northern parts of Xinjiang, while other parts of Central Asia were negative. The corresponding time coefficient showed a small annual variation. In Central Asia, the corresponding time coefficient for most years was greater than zero, which indicated that the spatial distribution of dry and wet in Central Asia would continue further.
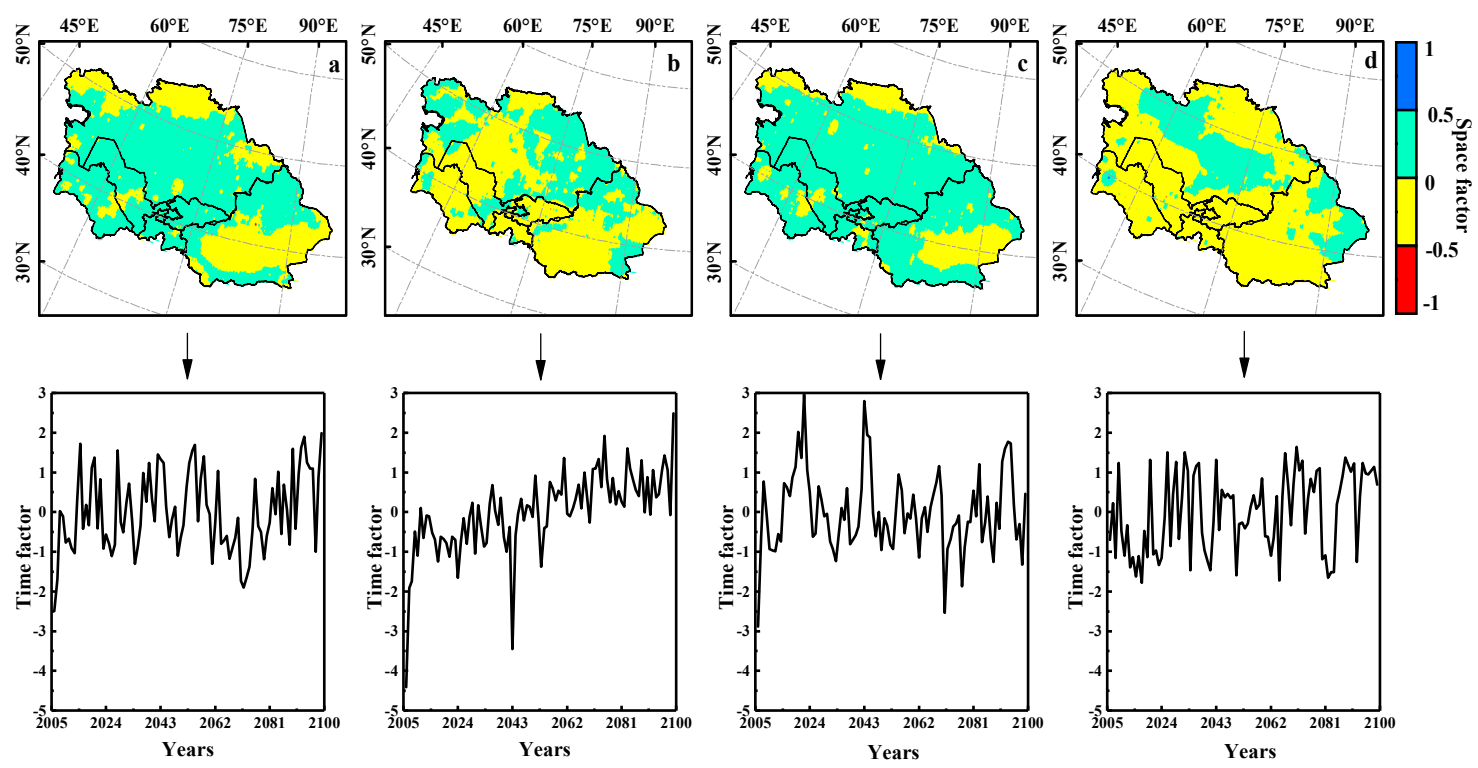

Figure 7. The spatial distribution of the first modal eigenvector field (above) and the corresponding temporal coefficient of the empirical orthogonal function (EOF) analysis (below) of the PDSI in Central Asia. (a) PDSI_PM under the $1.5^{\circ} \mathrm{C}$ warming scenario. (b) PDSI_PM under the $2.0^{\circ} \mathrm{C}$ warming scenario. (c) PDSI_TH under the $1.5^{\circ} \mathrm{C}$ warming scenario. (d) PDSI_TH under the $2.0^{\circ} \mathrm{C}$ warming scenario.

The spatial distribution of the PDSI calculated by two formulas (PM and TH) was similar in Central Asia under the $1.5{ }^{\circ} \mathrm{C}$ warming scenario, and the spatial coefficient for most of Central Asia was greater than zero. In the TH calculation, the corresponding time coefficient varied significantly year by year, which was similar to the variation trend of the results calculated by using the PM 
calculation. Under the $2.0^{\circ} \mathrm{C}$ warming scenario, the spatial distribution of the PDSI calculated by the two formulas was very different. In the TH calculation, only parts of central Kazakhstan and parts of northwest Xinjiang had a positive spatial coefficient, while the rest of Central Asia had a negative spatial coefficient. Compared to the calculation result of the PM calculation, this spatial distribution result was obviously different, and the regions with a positive spatial coefficient also showed a decrease. The temporal coefficient showed that the spatial trend of the dry-wet distribution in Central Asia changed significantly $(\alpha<0.05)$ on an interannual scale. When the time coefficient was positive, the central part of Kazakhstan and the eastern part of Xinjiang were in a humid state, and other parts of Central Asia were in a dry state: when the coefficient was negative, the distribution of dry and wet areas in Central Asia showed an opposite change (Figure $7 \mathrm{~b}, \mathrm{~d})$.

\subsection{Spatiotemporal Trend in the PDSI}

An analysis of the drought conditions was conducted using the proportion of the arid area to the total area and the PDSI trends in Central Asia under the warming scenarios. The proportion of arid areas in Central Asia fluctuated significantly from year to year. In the PM formula, the proportion of arid areas in Central Asia varied greatly under different warming scenarios, and the mean value of the proportion of arid areas was $54.2 \%$ and $38.9 \%\left(1.5^{\circ} \mathrm{C}\right.$ and $\left.2.0^{\circ} \mathrm{C}\right)$, respectively. The proportion of arid areas in Central Asia was significantly higher in the $1.5^{\circ} \mathrm{C}$ warming scenario than in the $2.0^{\circ} \mathrm{C}$ warming scenario (Figure $8 \mathrm{a}, \mathrm{c}$ ). Under the $1.5^{\circ} \mathrm{C}$ warming scenario, the maximum average proportion of arid areas during 2025-2040 was more than $60 \%$. Under the $2.0^{\circ} \mathrm{C}$ warming scenario, the proportion of arid areas in Central Asia was relatively low. The largest proportion of arid areas was found in $2025-2035$ and $2070-2090$, with values of $48.9 \%$ and $47.2 \%$, respectively. The average proportion of arid areas was $38.9 \%$, which was lower than in the $1.5^{\circ} \mathrm{C}$ scenario. After 2020 , the proportion of arid areas fluctuated greatly. The PDSI values calculated using the TH formula were similar to those calculated using the PM formula, with similar trends in the predicted proportion of arid areas in the future.

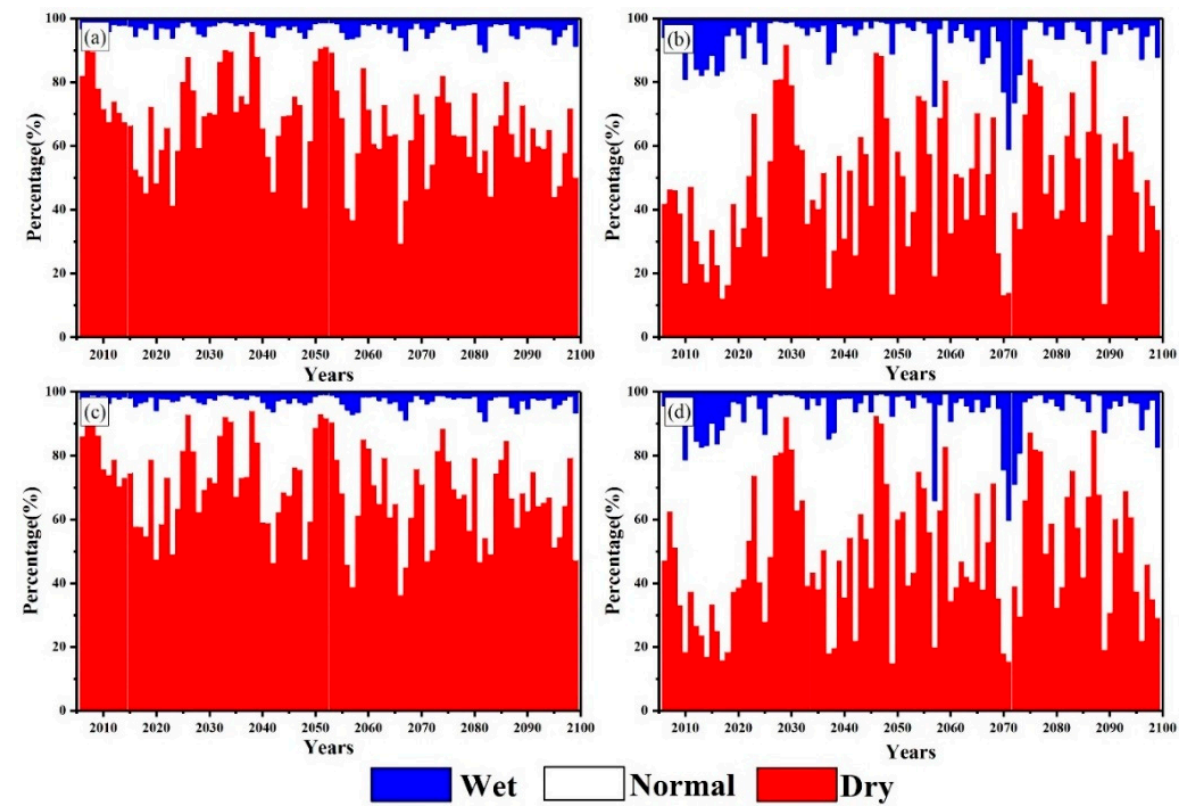

Figure 8. Temporal change in the proportion of arid/wet areas to total area in Central Asia. (a) PDSI_PM under the $1.5^{\circ} \mathrm{C}$ warming scenario. (b) PDSI_PM under the $2.0^{\circ} \mathrm{C}$ warming scenario. (c) PDSI_TH under the $1.5^{\circ} \mathrm{C}$ warming scenario. (d) PDSI_TH under the $2.0^{\circ} \mathrm{C}$ warming scenario.

The multiyear change rate in the PDSI under the warming scenarios was calculated separately for the two periods, namely 2006-2055 and 2056-2099. During 2006-2055, the change rate in the PDSI for most parts of Central Asia was -0.1 to $0.1 / 50$ years. In the PM calculation, negative PDSI rates 
of change were observed for most of northern Kazakhstan, western Xinjiang, and parts of Tajikistan and Uzbekistan, indicating increasing drought levels in the future. Positive change rates in the PDSI were evident in southern Kazakhstan and the northern regions of Xinjiang, indicating decreases in the magnitude of drought under the $1.5{ }^{\circ} \mathrm{C}$ warming scenario. Under the $2.0^{\circ} \mathrm{C}$ warming scenario, except for a small part of eastern Xinjiang, a negative change rate in the PDSI was evident, along with an increased magnitude of drought (Figure 9(a1,a2)).

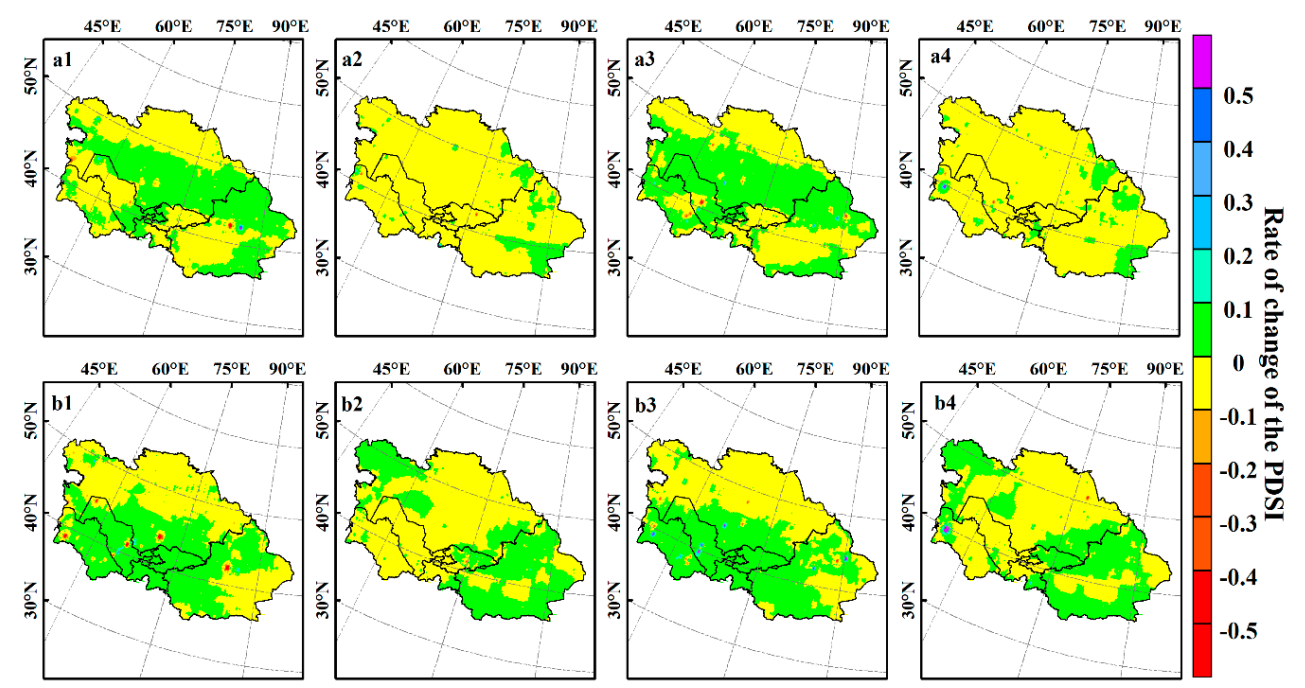

Figure 9. Spatial distribution of the multiyear change rate in the PDSI in Central Asia from 2006-2055 (a) and 2056-2099 (b). Numbers 1, 2, 3, and 4 in the top left-hand corners of the maps represent PDSI_PM under the $1.5^{\circ} \mathrm{C}$ warming scenario, PDSI_PM under the $2.0^{\circ} \mathrm{C}$ warming scenario, PDSI_TH under the $1.5^{\circ} \mathrm{C}$ warming scenario, and PDSI_TH under the $2.0^{\circ} \mathrm{C}$ warming scenario, respectively.

Compared to the results of the PM formula, the results from the TH formula showed that the areas with positive PDSI change rates increased. In the TH calculation, there were significant spatial distribution differences in the change rates in the PDSI in Central Asia under different warming scenarios. Under the $1.5{ }^{\circ} \mathrm{C}$ warming scenario, the spatial distribution of the PDSI change rate in Central Asia was similar to the result of the PM calculation, and the areas with a positive rate of change further expanded. Meanwhile, under the $2.0^{\circ} \mathrm{C}$ warming scenario, the areas with a positive PDSI change rate further decreased, and the areas with more severe drought in Central Asia further increased (in the future).

Between 2056 and 2099, the change rate in the PDSI across most of Central Asia was between -0.1 and 0.1/45 years. The area with a change rate in the PDSI greater than zero in 2056-2099 was significantly larger than that for the period 2006-2055. According to the PDSI calculation using the PM formula under the $1.5^{\circ} \mathrm{C}$ warming scenario, the change rate in the PDSI for most of the southern parts of Central Asia, namely Turkmenistan, Tajikistan, and Uzbekistan, was positive, and a wetting trend was evident. In most parts of Kazakhstan and parts of eastern Xinjiang, the change rate in the PDSI was negative, and a drought trend was evident. Under the $2.0^{\circ} \mathrm{C}$ warming scenario, the area of Central Asia with reduced drought intensity was significantly smaller than that under the $1.5^{\circ} \mathrm{C}$ scenario. Regions with positive PDSI variability were concentrated in western and eastern Kazakhstan and most of Xinjiang, where drought conditions were expected to weaken between 2056 and 2099. The area with an increased change rate in the PDSI calculated using the TH formula was almost the same as that calculated using the PM formula, but the distribution was different. A positive change rate in the PDSI was concentrated mainly in the eastern part of Xinjiang and the western part of Kazakhstan, with the values in certain areas exceeding $0.2 / 45$ years (Figure $9(\mathrm{~b} 1-\mathrm{b} 4)$ ). 


\section{Discussion}

\subsection{Influence of Different Evapotranspiration Calculation Methods on the PDSI}

The calculation of potential evapotranspiration is an important part of the PDSI calculation process [64]. In the original PDSI model, the Thornthwaite empirical formula was used to calculate potential evapotranspiration due to the difficulty in collecting long-term observations of a variety of meteorological elements. The Thornthwaite formula needs only two variables, temperature and latitude. This formula has low requirements for input data in the calculation of evapotranspiration and has therefore been widely used [46]. However, the Thornthwaite formula also has certain problems. In the context of global warming, the relationship between short-wave radiation and potential evapotranspiration estimated using the Thornthwaite formula based on a certain latitude and temperature will also change, which will lead to an error in the calculation of the potential future evapotranspiration [65]. In contrast, the Penman-Monteith formula is more accurate in calculating potential evapotranspiration $[66,67]$.

In our study, the calculation of the PDSI was performed using two calculation methods for potential evapotranspiration (PDSI_TH and PDSI_PM). The results showed that under the $1.5^{\circ} \mathrm{C}$ warming scenario, the average PDSI values in Central Asia were -1.35 and -1.51 for the PDSI_PM and PDSI_TH methods, respectively, while the drought frequencies were $67.6 \%$ and $71.3 \%$, respectively. The proportion of arid areas calculated using the PM formula was 49.8\%, which was slightly lower than the result obtained using the TH formula, 51.5\%. Compared to the PM method, the TH method showed an overestimation of both the drought frequency and the proportion of arid areas in Central Asia, showing more severe drought in Central Asia. This result was consistent with the findings of Sheffield [68]. Affected by global warming, further changes in the relationship between precipitation and evapotranspiration will directly affect the underlying surface water balance, which will affect the frequency, intensity, and duration of drought $[69,70]$. Compared to the PM formula, the use of the $\mathrm{TH}$ formula leads to an error in the potential evapotranspiration calculation [71,72], which in turn leads to an overestimation of future drought frequency and risk conditions, which is more pronounced in the context of global warming [68]. Therefore, in PDSI calculations, continuous improvements to the potential evapotranspiration calculation method are the key to improving the accuracy of drought simulation.

\subsection{Characteristics of Drought Variation in Central Asia under Different Warming Scenarios}

Many studies have shown that with the impact of global temperature increases, the frequency, duration, and intensity of droughts in most parts of the world under different warming scenarios $\left(1.5^{\circ} \mathrm{C}\right.$ and $\left.2.0^{\circ} \mathrm{C}\right)$ will all increase to some extent $[73,74]$. Due to the influence of precipitation, temperature, evaporation, and other factors, there are obvious differences in the risk, degree, duration, and impact range of droughts and in the losses caused by them in different regions of the world under different warming scenarios. There is not a simple linear relationship between the effects and risks of drought and temperature increases [75].

In our study, drought frequency, the proportion of arid areas, and the future variations in drought in Central Asia were analyzed under two warming scenarios $\left(1.5^{\circ} \mathrm{C}\right.$ and $\left.2.0^{\circ} \mathrm{C}\right)$. There was a large gap between the final results and previous estimations. Compared to a temperature increase of $1.5^{\circ} \mathrm{C}$, an additional $0.5^{\circ} \mathrm{C}$ increase (i.e., to $2.0^{\circ} \mathrm{C}$ ) would not lead to a significant increase in the drought frequency and the proportion of arid areas in Central Asia. On the contrary, under the $2.0^{\circ} \mathrm{C}$ warming scenario, the drought frequency and the proportion of arid areas both decreased. The results obtained using the two PDSI calculation methods showed the same PDSI change trend: that is, under the $1.5^{\circ} \mathrm{C}$ warming scenario, the drought frequency and proportion of arid areas in Central Asia were higher than those under the $2.0^{\circ} \mathrm{C}$ warming scenario. Under both warming scenarios, the PDSI in Central Asia further decreased, and the drought situation further worsened. This result is consistent with Huang et al. [3]. However, we also found that drought conditions in Central Asia were likely to be 
more severe in the $1.5{ }^{\circ} \mathrm{C}$ warming scenario than under the $2.0^{\circ} \mathrm{C}$ warming scenario. The rise in temperature will lead to changes in precipitation and evaporation, both of which have varying degrees of impact on a drought index. Additionally, the rise in temperature will have a significant impact on the glacier snowmelt process in the inland region [76]. With the rise in temperature, the gradual acceleration of snow melting may have an inhibitory effect on drought in the downstream region. A study by Liu et al. [77] on the population affected by drought under global warming scenarios showed that in northeast Central Asia, the PDSI value under the $1.5^{\circ} \mathrm{C}$ warming scenario was slightly lower than that under the $2.0^{\circ} \mathrm{C}$ warming scenario, and the duration of drought was longer under the $1.5^{\circ} \mathrm{C}$ warming scenario than that under the $2.0^{\circ} \mathrm{C}$ scenario. Furthermore, the results of a study by Naumann et al. [78] also showed that with the influence of global warming, the water supply from the underlying surface in northwestern China will be improved, which will alleviate local drought to some extent.

\section{Conclusions}

In this study, we used the PDSI_PM and PDSI_TH methods to estimate the occurrence of drought in Central Asia under two global warming scenarios using ISIMIP datasets. The key conclusions of this study are as follows:

1. Under the $1.5^{\circ} \mathrm{C}$ and $2.0^{\circ} \mathrm{C}$ warming scenarios, the PDSI of Central Asia showed a decreasing trend, indicating worsening drought conditions. The annual average PDSI value in Central Asia under the $1.5^{\circ} \mathrm{C}$ warming scenario was -1.36 , which was lower than the value of -0.98 obtained for the $2.0^{\circ} \mathrm{C}$ warming scenario. The PDSI variation trend obtained using the two calculation methods (PDSI_PM and PDSI_TH) was similar: that is, under both warming scenarios, the PDSI in Central Asia showed a significant decrease compared to the base period, and the future drought trend was significant. The M-K trend analysis also indicated that the PDSI initially increased and then decreased for the four scenarios (the $1.5^{\circ} \mathrm{C}$ warming scenario using the PM formula, the $1.5^{\circ} \mathrm{C}$ scenario using the $\mathrm{TH}$ formula, the $2.0^{\circ} \mathrm{C}$ scenario using the PM formula, and the $2.0^{\circ} \mathrm{C}$ scenario using the TH formula). After 2050, a downward trend in the PDSI was observed $(\alpha=0.05)$. Under the two warming scenarios, the change point of the PDSI in Central Asia appeared in 2080-2090 and 2020-2025, respectively. The change rates in the PDSI under the $1.5^{\circ} \mathrm{C}$ and $2.0^{\circ} \mathrm{C}$ warming scenarios were $-0.0164 /$ per decade and $-0.0135 /$ per decade, respectively. The change rates of the PDSI were similar for the PDSI_PM and PDSI_TH methods. Under the $1.5^{\circ} \mathrm{C}$ and $2.0^{\circ} \mathrm{C}$ warming scenarios, the proportion of arid areas (PDSI $<-1$ ) in Central Asia was $54.2 \%$ and $38.9 \%$, respectively.

2. The EOF analysis showed that there were large differences in the spatial distribution of drought in Central Asia under the two warming scenarios. Under the $1.5^{\circ} \mathrm{C}$ warming scenario, most parts of Central Asia would be in a humid state, while southern Xinjiang, parts of northern Kazakhstan, and parts of Turkmenistan would experience drought. The distribution of dry and wet areas in Central Asia was predicted to change frequently in the future. Under the $2.0^{\circ} \mathrm{C}$ warming scenario, most parts of Kazakhstan and northern parts of Xinjiang showed a wet state, while other regions in Central Asia presented a dry state. The different PDSI calculation methods (PDSI_PM and PDSI_TH) showed significantly different spatial distributions of drought in Central Asia. The spatial distribution characteristics of drought in Central Asia were predicted to change frequently in the future. Under the $1.5^{\circ} \mathrm{C}$ warming scenario, the drought frequency in most parts of Central Asia was $60-80 \%$, with an average of $67.6 \%$, whereas under the $2.0^{\circ} \mathrm{C}$ warming scenario, the average drought frequency was $54.8 \%$.

3. The PDSI values obtained using different calculation formulas for potential evapotranspiration were different. There were some differences in the drought conditions obtained by the two PDSI calculation methods (PDSI_PM and PDSI_TH) in Central Asia for the two future warming scenarios. The average annual PDSI values for Central Asia obtained using PDSI_PM and PDSI_TH were -1.35 and -1.51 , respectively. The drought frequency $(71.3 \%)$ and the proportion 
of arid areas (55.4\%) obtained for Central Asia using the TH formula were higher than those obtained using the PM formula (drought frequency and proportion of arid areas of $67.6 \%$ and $54.8 \%$, respectively). Under the warming scenarios, the use of the $\mathrm{TH}$ formula led to an error in the calculation of potential evapotranspiration, which in turn led to problems in the calculation of the PDSI. Compared to the PM formula, the TH formula led to an overestimation of the drought situation in Central Asia under both warming scenarios.

4. The drought situation in Central Asia would be further aggravated under both warming scenarios. Under the $1.5^{\circ} \mathrm{C}$ warming scenario, the calculated PDSI value in Central Asia was lower than that under the $2.0^{\circ} \mathrm{C}$ warming scenario, while the drought frequency and proportion of arid areas were significantly higher than those under the $2.0^{\circ} \mathrm{C}$ warming scenario. Compared to the $2.0^{\circ} \mathrm{C}$ warming scenario, the drought situation in Central Asia may be more serious under the $1.5^{\circ} \mathrm{C}$ warming scenario. This research improves human cognition of the drought process in Central Asia under global warming and enhances regional security and construction of the Silk Road Economic Belt.

Author Contributions: Conceptualization, R.Z., X.M., C.Z., and K.B.; formal analysis, C.Z.; funding acquisition, C.Z.; methodology, R.Z., Q.H., C.L., and X.M.; resources, C.Z. and X.Z.; supervision, C.Z. and K.B.; visualization, C.Z.; writing—original draft, R.Z. and X.M.; writing—review and editing, C.Z. and X.Z.

Funding: This research was funded by the Strategic Priority Research Program of the Chinese Academy of Sciences (XDA2006030201) and the key project of the National Natural Science Foundation (U1403281, 41671030).

Acknowledgments: We sincerely thank three anonymous reviewers for their valuable comments and suggestions, which helped improve the manuscript. We thank MDPI and American Journal Experts for their linguistic assistance during the preparation of this manuscript.

Conflicts of Interest: The authors declare no conflicts of interest. The funders had no role in the design of the study; in the collection, analyses, or interpretation of data; in the writing of the manuscript; or in the decision to publish the results.

\section{References}

1. Tian-Jun, Z.; Tao, H. Projected changes of palmer drought severity index under an RCP8. 5 scenario. Atmos. Ocean. Sci. Lett. 2013, 6, 273-278. [CrossRef]

2. Yang, P.; Xia, J.; Zhang, Y.Y.; Zhan, C.S.; Qiao, Y.F. Comprehensive assessment of drought risk in the arid region of Northwest China based on the global palmer drought severity index gridded data. Sci. Total Environ. 2018, 627, 951-962. [CrossRef] [PubMed]

3. Huang, J.P.; Yu, H.P.; Dai, A.G.; Wei, Y.; Kang, L.T. Drylands face potential threat under 2 degrees C global warming target. Nat. Clim. Chang. 2017, 7, 417-422. [CrossRef]

4. Wilhite, D.A. Drought as a Natural Hazard: Concepts and Definitions. 2000. Available online: https: //digitalcommons.unl.edu/droughtfacpub/69 (accessed on 14 August 2019).

5. Trenberth, K.; Jones, P.; Ambenje, P.; Bojariu, R.; Easterling, D.; Klein Tank, A.; Parker, D.; Rahimzadeh, F.; Renwick, J.; Rusticucci, M. Observations: Surface and Atmospheric Climate Change. Chapter 3. Climate change. 2007, pp. 235-336. Available online: https://www.ipcc.ch/report/ar4/wg1/observations-atmosphericsurface-and-climate-change/ (accessed on 5 August 2019).

6. Dai, A. Drought under global warming: A review. Wiley Interdiscip. Rev. Clim. Chang. 2011, 2, 45-65. [CrossRef]

7. UNFCCC. UNFCCC Conference of the Parties: Adoption of the Paris Agreement; FCCC/CP/2015/10Add. 1; UNFCCC: Paris, France, 2015.

8. IPCC. Climate Change 2013: The Physical Science Basis. In Contribution of Working Group I to the Fifth Assessment Report of the Intergovernmental Panel on Climate Change; Stocker, T.F., Qin, D., Plattner, G.-K., Tignor, M., Allen, S.K., Boschung, J., Nauels, A., Xia, Y., Bex, V., Midgley, P.M., Eds.; Cambridge University Press: Cambridge, UK; New York, NY, USA, 2013; 1535p.

9. Vicenteserrano, S.M.; Beguería, S.; Lorenzolacruz, J.; Camarero, J.J.; Lópezmoreno, J.I.; Azorinmolina, C.; Revuelto, J.; Morántejeda, E.; Sanchezlorenzo, A. Performance of Drought Indices for Ecological, Agricultural, and Hydrological Applications. Earth Interact. 2012, 16, 1-27. [CrossRef] 
10. Tsakiris, G.; Nalbantis, I.; Vangelis, H.; Verbeiren, B.; Huysmans, M.; Tychon, B.; Jacquemin, I.; Canters, F.; Vanderhaegen, S.; Engelen, G. A system-based paradigm of drought analysis for operational management. Water Resour. Manag. 2013, 27, 5281-5297. [CrossRef]

11. Wilhite, D.A.; Glantz, M.H. Understanding: The drought phenomenon: The role of definitions. Water Int. 1985, 10, 111-120. [CrossRef]

12. Heim, R.R., Jr. A review of twentieth-century drought indices used in the United States. Bull. Am. Meteorol. Soc. 2002, 83, 1149-1166. [CrossRef]

13. Svoboda, M.; LeComte, D.; Hayes, M.; Heim, R.; Gleason, K.; Angel, J.; Rippey, B.; Tinker, R.; Palecki, M.; Stooksbury, D. The drought monitor. Bull. Am. Meteorol. Soc. 2002, 83, 1181-1190. [CrossRef]

14. Yan, H.X.; Zarekarizi, M.; Moradkhani, H. Toward improving drought monitoring using the remotely sensed soil moisture assimilation: A parallel particle filtering framework. Remote Sens. Environ. 2018, 216, 456-471. [CrossRef]

15. Yan, H.X.; Moradkhani, H.; Zarekarizi, M. A probabilistic drought forecasting framework: A combined dynamical and statistical approach. J. Hydrol. 2017, 548, 291-304. [CrossRef]

16. Ahmadalipour, A.; Moradkhani, H.; Yan, H.; Zarekarizi, M. Remote Sensing of Drought: Vegetation, Soil Moisture, and Data Assimilation. In Remote Sensing of Hydrological Extremes; Lakshmi, V., Ed.; Springer International Publishing: Cham, Switzerland, 2017; pp. 121-149.

17. Vicente-Serrano, S.M.; López-Moreno, J.I.; Lorenzo-Lacruz, J.; El Kenawy, A.; Azorin-Molina, C.; Morán-Tejeda, E.; Pasho, E.; Zabalza, J.; Beguería, S.; Angulo-Martínez, M. The NAO impact on droughts in the Mediterranean region. In Hydrological, Socioeconomic and Ecological Impacts of the North Atlantic Oscillation in the Mediterranean Region; Springer: Dordrecht, The Netherlands, 2011; pp. 23-40.

18. Mishra, A.K.; Singh, V.P. A review of drought concepts. J. Hydrol. 2010, 391, 202-216. [CrossRef]

19. Palmer, W.C. Meteorological Drought, Research Paper no. 45; US Weather Bureau: Washington, DC, USA, 1965; Volume 58.

20. Barling, R.D.; Moore, I.D.; Grayson, R.B. A quasi-dynamic wetness index for characterizing the spatial distribution of zones of surface saturation and soil water content. Water Resour. Res. 1994, 30, 1029-1044. [CrossRef]

21. Hayes, M.J.; Svoboda, M.D.; Wilhite, D.A.; Vanyarkho, O.V. Monitoring the 1996 Drought Using the Standardized Precipitation Index. Bull. Am. Meteorol. Soc. 1999, 80, 429-438. [CrossRef]

22. Vicente-Serrano, S.M.; Beguería, S.; López-Moreno, J.I. A multiscalar drought index sensitive to global warming: The standardized precipitation evapotranspiration index. J. Clim. 2010, 23, 1696-1718. [CrossRef]

23. Karl, T.R.; Koscielny, A.J. Drought in the united states: 1895-1981. J. Climatol. 1982, 2, 313-329. [CrossRef]

24. Alley, W.M. The Palmer drought severity index: Limitations and assumptions. J. Clim. Appl. Meteorol. 1984, 23, 1100-1109. [CrossRef]

25. Dai, A.; Trenberth, K.E.; Karl, T.R. Global variations in droughts and wet spells: 1900-1995. Geophys. Res. Lett. 1998, 25, 3367-3370. [CrossRef]

26. Wells, N.; Goddard, S.; Hayes, M.J. A self-calibrating Palmer drought severity index. J. Clim. 2004, 17, 2335-2351. [CrossRef]

27. Van der Schrier, G.; Briffa, K.; Osborn, T.; Cook, E. Summer moisture availability across North America. J. Geophys. Res. Atmos. 2006, 111, D11. [CrossRef]

28. Dai, A. Characteristics and trends in various forms of the Palmer Drought Severity Index during 1900-2008. J. Geophys. Res. Atmos. 2011, 116, D12. [CrossRef]

29. Gao, L.; Gou, X.; Deng, Y.; Yang, M.; Zhao, Z.; Cao, Z. Dendroclimatic response of Picea crassifolia along an altitudinal gradient in the eastern Qilian Mountains, northwest China. Arct. Antarct. Alp. Res. 2013, 45, 491-499. [CrossRef]

30. Wang, H.; Chen, Y.; Pan, Y.; Li, W. Spatial and temporal variability of drought in the arid region of China and its relationships to teleconnection indices. J. Hydrol. 2015, 523, 283-296. [CrossRef]

31. Wondie, M.; Terefe, T. Assessment of drought in Ethiopia by using self-calibrated Palmer Drought Severity Index. Int. J. Eng. Manag. Sci. 2016, 7, 108-117.

32. Heddinghaus, T.R.; Sabol, P. A review of the Palmer Drought Severity Index and where do we go from here. In Proceedings of the 7th Conference on Applied Climatology, Salt Lake City, UT, USA, 10-13 September 1991; American Meteorological Society: Boston, MA, USA, 1991; pp. 242-246. 
33. Dai, A. Increasing drought under global warming in observations and models. Nat. Clim. Chang. 2013, 3, 52-58. [CrossRef]

34. Van der Schrier, G.; Jones, P.D.; Briffa, K.R. The sensitivity of the PDSI to the Thornthwaite and Penman-Monteith parameterizations for potential evapotranspiration. J. Geophys. Res. Atmos. 2011, 116, 16. [CrossRef]

35. Ma, X.; Zhao, C.; Tao, H.; Zhu, J.; Kundzewicz, Z.W. Projections of actual evapotranspiration under the 1.5 ${ }^{\circ} \mathrm{C}$ and $2.0^{\circ} \mathrm{C}$ global warming scenarios in sandy areas in northern China. Sci. Total Environ. 2018, 645, 1496-1508. [CrossRef]

36. Su, B.; Huang, J.; Fischer, T.; Wang, Y.; Kundzewicz, Z.W.; Zhai, J.; Sun, H.; Wang, A.; Zeng, X.; Wang, G. Drought losses in China might double between the $1.5^{\circ} \mathrm{C}$ and $2.0^{\circ} \mathrm{C}$ warming. Proc. Natl. Acad. Sci. USA 2018, 115, 10600-10605. [CrossRef]

37. Huang, J.P.; Ji, M.X.; Xie, Y.K.; Wang, S.S.; He, Y.L.; Ran, J.J. Global semi-arid climate change over last 60 years. Clim. Dyn. 2016, 46, 1131-1150. [CrossRef]

38. Collins, M.; Knutti, R.; Arblaster, J.; Dufresne, J.-L.; Fichefet, T.; Friedlingstein, P.; Gao, X.; Gutowski, W.J.; Johns, T.; Krinner, G. Long-term climate change: Projections, commitments and irreversibility. In Climate Change 2013-The Physical Science Basis: Contribution of Working Group I to the Fifth Assessment Report of the Intergovernmental Panel on Climate Change; Cambridge University Press: Cambridge, UK, 2013; pp. 1029-1136. Available online: https://www.ipcc.ch/report/ar5/wg1/ (accessed on 14 August 2019).

39. Kim, D.-W.; Byun, H.-R. Future pattern of Asian drought under global warming scenario. Theor. Appl. Climatol. 2009, 98, 137-150. [CrossRef]

40. Fang, K.; Gou, X.; Chen, F.; Davi, N.; Liu, C. Spatiotemporal drought variability for central and eastern Asia over the past seven centuries derived from tree-ring based reconstructions. Quat. Int. 2013, 283, 107-116. [CrossRef]

41. Touma, D.; Ashfaq, M.; Nayak, M.A.; Kao, S.-C.; Diffenbaugh, N.S. A multi-model and multi-index evaluation of drought characteristics in the 21st century. J. Hydrol. 2015, 526, 196-207. [CrossRef]

42. Sun, H.; Wang, A.; Zhai, J.; Huang, J.; Wang, Y.; Wen, S.; Zeng, X.; Su, B. Impacts of global warming of $1.5 \mathrm{C}$ and $2.0 \mathrm{C}$ on precipitation patterns in China by regional climate model (COSMO-CLM). Atmos. Res. 2018, 203, 83-94. [CrossRef]

43. Jahani, B.; Mohammadi, B. A comparison between the application of empirical and ANN methods for estimation of daily global solar radiation in Iran. Theor. Appl. Climatol. 2019, 137, 1257-1269. [CrossRef]

44. Taylor, K.E.; Stouffer, R.J.; Meehl, G.A. An overview of CMIP5 and the experiment design. Bull. Am. Meteorol. Soc. 2012, 93, 485-498. [CrossRef]

45. Wu, F.; Fang, X.; Herrmann, M.; Mosbrugger, V.; Miao, Y. Extended drought in the interior of Central Asia since the Pliocene reconstructed from sporopollen records. Glob. Planet. Chang. 2011, 76, 16-21. [CrossRef]

46. Burke, E.J.; Brown, S.J.; Christidis, N. Modeling the recent evolution of global drought and projections for the twenty-first century with the hadley centre climate model. J. Hydrometeorol. 2006, 7, 1113-1125. [CrossRef]

47. Zhang, Y.; Fu, L.; Pan, J.; Xu, Y. Projected changes in temperature extremes in China using PRECIS. Atmosphere 2017, 8, 15. [CrossRef]

48. Jiang, D.; Sui, Y.; Lang, X. Timing and associated climate change of a 2 C global warming. Int. J. Climatol. 2016, 36, 4512-4522. [CrossRef]

49. Schlaepfer, D.R.; Bradford, J.B.; Lauenroth, W.K.; Munson, S.M.; Tietjen, B.; Hall, S.A.; Wilson, S.D.; Duniway, M.C.; Jia, G.; Pyke, D.A. Climate change reduces extent of temperate drylands and intensifies drought in deep soils. Nat. Commun. 2017, 8, 14196. [CrossRef]

50. Davi, N.K.; Jacoby, G.C.; Curtis, A.E.; Baatarbileg, N. Extension of drought records for central Asia using tree rings: West-central Mongolia. J. Clim. 2006, 19, 288-299. [CrossRef]

51. Shahabfar, A.; Ghulam, A.; Conrad, C. Understanding hydrological repartitioning and shifts in drought regimes in Central and South-West Asia using MODIS derived perpendicular drought index and TRMM data. IEEE J. Sel. Top. Appl. Earth Obs. Remote Sens. 2013, 7, 983-993. [CrossRef]

52. Reyer, C.P.O.; Otto, I.M.; Adams, S.; Albrecht, T.; Baarsch, F.; Cartsburg, M.; Coumou, D.; Eden, A.; Ludi, E.; Marcus, R.; et al. Climate change impacts in Central Asia and their implications for development. Reg. Environ. Chang. 2017, 17, 1639-1650. [CrossRef]

53. Chen, F.; Huang, W.; Jin, L.; Chen, J.; Wang, J. Spatiotemporal precipitation variations in the arid Central Asia in the context of global warming. Sci. China Earth Sci. 2011, 54, 1812-1821. [CrossRef] 
54. Huang, J.; Qin, D.; Jiang, T.; Wang, Y.; Feng, Z.; Zhai, J.; Cao, L.; Chao, Q.; Xu, X.; Wang, G. Effect of Fertility Policy Changes on the Population Structure and Economy of China: From the Perspective of the Shared Socioeconomic Pathways. Earth's Future 2019, 7, 250-265. [CrossRef]

55. King, A.D.; Karoly, D.J.; Henley, B.J. Australian climate extremes at 1.5 degrees $C$ and 2 degrees $C$ of global warming. Nat. Clim. Chang. 2017, 7, 412-416. [CrossRef]

56. Warszawski, L.; Frieler, K.; Huber, V.; Piontek, F.; Serdeczny, O.; Schewe, J. The Inter-Sectoral Impact Model Intercomparison Project (ISI-MIP): Project framework. Proc. Natl. Acad. Sci. USA 2014, 111, 3228-3232. [CrossRef] [PubMed]

57. Dai, A.; Trenberth, K.E.; Qian, T.T. A global dataset of Palmer Drought Severity Index for 1870-2002: Relationship with soil moisture and effects of surface warming. J. Hydrometeorol. 2004, 5, 1117-1130. [CrossRef]

58. Jacobi, J.; Perrone, D.; Duncan, L.L.; Hornberger, G. A tool for calculating the Palmer drought indices. Water Resour. Res. 2013, 49, 6086-6089. [CrossRef]

59. Ficklin, D.L.; Letsinger, S.L.; Gholizadeh, H.; Maxwell, J.T. Incorporation of the Penman-Monteith potential evapotranspiration method into a Palmer Drought Severity Index tool. Comput. Geosci. 2015, 85, 136-141. [CrossRef]

60. Mann, H.B. Nonparametric tests against trend. Econom. J. Econom. Soc. 1945, 13, 245-259. [CrossRef]

61. Montroy, D.L. Linear relation of central and eastern North American precipitation to tropical Pacific sea surface temperature anomalies. J. Clim. 1997, 10, 541-558. [CrossRef]

62. Hannachi, A.; Jolliffe, I.T.; Stephenson, D.B. Empirical orthogonal functions and related techniques in atmospheric science: A review. Int. J. Climatol. 2010, 27, 1119-1152. [CrossRef]

63. Jiang, L.L.; Jiapaer, G.; Bao, A.M.; Kurban, A.; Guo, H.; Zheng, G.X.; De Maeyer, P. Monitoring the long-term desertification process and assessing the relative roles of its drivers in Central Asia. Ecol. Indic. 2019, 104, 195-208. [CrossRef]

64. Cook, B.I.; Smerdon, J.E.; Seager, R.; Coats, S. Global warming and 21 st century drying. Clim. Dyn. 2014, 43, 2607-2627. [CrossRef]

65. Burke, E.J.; Brown, S.J. Evaluating uncertainties in the projection of future drought. J. Hydrometeorol. 2008, 9, 292-299. [CrossRef]

66. Donohue, R.J.; Roderick, M.L.; McVicar, T.R. On the importance of including vegetation dynamics in Budyko's hydrological model. Hydrol. Earth Syst. Sci. 2007, 11, 983-995. [CrossRef]

67. Lockwood, J. Is potential evapotranspiration and its relationship with actual evapotranspiration sensitive to elevated atmospheric $\mathrm{CO}_{2}$ levels? Clim. Chang. 1999, 41, 193-212. [CrossRef]

68. Sheffield, J.; Wood, E.F.; Roderick, M.L. Little change in global drought over the past 60 years. Nature 2012, 491, 435. [CrossRef]

69. Huang, J.P.; Yu, H.P.; Guan, X.D.; Wang, G.Y.; Guo, R.X. Accelerated dryland expansion under climate change. Nat. Clim. Chang. 2016, 6, 166-171. [CrossRef]

70. Sherwood, S.; Fu, Q. A drier future? Science 2014, 343, 737-739. [CrossRef] [PubMed]

71. Donohue, R.J.; McVicar, T.R.; Roderick, M.L. Assessing the ability of potential evaporation formulations to capture the dynamics in evaporative demand within a changing climate. J. Hydrol. 2010, 386, 186-197. [CrossRef]

72. Hobbins, M.T.; Dai, A.; Roderick, M.L.; Farquhar, G.D. Revisiting the parameterization of potential evaporation as a driver of long-term water balance trends. Geophys. Res. Lett. 2008, 35. [CrossRef]

73. Cook, B.I.; Mankin, J.S.; Anchukaitis, K.J. Climate change and drought: From past to future. Curr. Clim. Chang. Rep. 2018, 4, 164-179. [CrossRef]

74. Smirnov, O.; Zhang, M.; Xiao, T.; Orbell, J.; Lobben, A.; Gordon, J. The relative importance of climate change and population growth for exposure to future extreme droughts. Clim. Chang. 2016, 138, 41-53. [CrossRef]

75. Lehner, F.; Coats, S.; Stocker, T.F.; Pendergrass, A.G.; Sanderson, B.M.; Raible, C.C.; Smerdon, J.E. Projected drought risk in 1.5 C and 2 C warmer climates. Geophys. Res. Lett. 2017, 44, 7419-7428. [CrossRef]

76. Diffenbaugh, N.S.; Scherer, M.; Ashfaq, M. Response of snow-dependent hydrologic extremes to continued global warming. Nat. Clim. Chang. 2013, 3, 379-384. [CrossRef] 
77. Liu, W.; Sun, F.; Lim, W.H.; Zhang, J.; Wang, H.; Shiogama, H.; Zhang, Y. Global drought and severe drought-affected populations in 1.5 and $2{ }^{\circ} \mathrm{C}$ warmer worlds. Earth Syst. Dyn. 2018, 9, 267-283. [CrossRef]

78. Naumann, G.; Alfieri, L.; Wyser, K.; Mentaschi, L.; Betts, R.; Carrao, H.; Spinoni, J.; Vogt, J.; Feyen, L. Global changes in drought conditions under different levels of warming. Geophys. Res. Lett. 2018, 45, 3285-3296. [CrossRef] 